\title{
A New Approach in Providing Water to Isolated Communities by Exploitation of Sustainable Energy Resources in Dry and Semi-dry Areas in Saudi Arabia
}

\author{
Jamal Mohammad Amous \\ Chemical Engineering Department, Faculty of Engineering, University of Hail, Hail, Kingdom of Saudi Arabia
}

Copyright $\bigcirc 2018$ by authors, all rights reserved. Authors agree that this article remains permanently open access under the terms of the Creative Commons Attribution License 4.0 International License

\begin{abstract}
The Arab countries, especially Saudi Arabia, occupy a prominent place in terms of their uniqueness of proximity to many sources of alternative energy. They are characterized for their long sun shining hours, e.g. Saudi Arabia is of a prime location to harness solar energy because of its year-round sunshine. The average energy from the sunlight falling on Saudi Arabia is 2200 thermal $\mathrm{kWh} / \mathrm{m}^{2}$. The winds perpetual motion, differences in weather conditions between different areas of the KSA create the opportunity for active air currents. It is characterized by an abundance of plenty underground soft water, salty water traps and plenty amounts of waste waters all over the country. Saudi Arabia was producing $18 \%$ of the worlds desalinated waters, It sounds as though the Kingdom recognizes the solar and winds potential it owns, that can be utilized for improving the level of life for the majority of its inhabitants especially those living in dry and or semi-dry isolated places which can be attained by providing the necessary quantities of water for individuals and for governmental interests in these areas.
\end{abstract}

Keywords Energy, Water, Evaporation, Heating, Surface Tension, Suspended Solids

\section{Introduction}

Water is critical and of great importance in many areas of the Arab countries due to its limited resources with an average yearly rainfall around $100 \mathrm{~mm}$. compared with other countries with rivers and water bodies of lakes and fresh water surfaces, these areas are under extreme water shortage conditions. Billions of cubic meters of water are produced around the world Desalinating sea waters with costs approaching 1 U\$ A per cubic meter [1]. The production of fresh water requires a large amount of energy. Pascale Compaina [2] reported that every $1000 \mathrm{~m}^{3}$ of freshwater per day requires 10000 tons of oil per year. Reverse Osmosis(RO) capacity has increased in the last 30 years to reach approximately $45-50 \%$ of the desalinated total capacity. Unit water cost was lowered due to the developments in RO and is now about $0,5 \mathrm{US} \$ / \mathrm{m}^{3}$ treated water. The costing of water unit applying different technologies reported by Pascale Compaina[2], now is for Multi Stage Flash Distillation around $0.5 \mathrm{US} \$ / \mathrm{m}^{3}$ while for Multi Effect Distillation the unit price is around 0.7 $\mathrm{US} \$ \mathrm{~m}^{3}$.

Knowing that in dry and semi dry regions receiving huge intensity of solar radiation desalination is essential. It comes as an evidence to use solar power for running water treatment plants, where Solar technologies can produce heat and thus electricity through a turbine applying concentrating solar power technology (CSP). Growing interests and developments on CSP as well as PV(Photovoltaic), tend to make these technologies more and more attractive[2].

Saudi Arabia (KSA) with an area of about 2.25 million $\mathrm{Km}^{2}$ and total population of about 30 million, passed three decades experiencing comprehensive developments coupled with remarkable growth rates in population and living standards.

These were accompanied with increasing water consumption in the agricultural, municipal and industrial sectors [3].

During the last decade, the average water share per capita was in the range between 250 and $350 \mathrm{~m}^{3} /$ year. According to the scarcity index, the country is under water shortage condition [4]. On an average, the municipal sector consumes about 260 liters water per capita per day [5].

Saudi Arabia consumes 24 billion cubic meter water per year, and agriculture is the leading sector with $88 \%$ usage, municipal sector 9\% usage and industrial sector accounts $3 \%$ usage of total water consumption[6].

More than $60 \%$ of the water demand for municipality services and covering the industrial sector needs is being 
supplied from groundwater resources while the remaining $35 \%$ is met by other technologies, mainly utilizing desalination plants. The available data of 1999-2004 show an increasing trend in internal migration to the main cities, accompanied with $3 \%$ population growth which had a result of $4.5 \%$ increase in the consumption of municipal water [7]. The available water resources data shows that Saudi Arabia will not be able to meet the domestic food demands making it a food importing country. Irrigation of municipal yards and green street landscape areas, the treated wastewater is abundantly used. On country basis survey during 2010, approximately 250 million cubic meters of wastewater after treatment was used for landscape and crop irrigation [8]. Tables $1 \mathrm{a}, 1 \mathrm{~b}$ show the available quantities of water from all sources conventional and non-conventional sources and it shows also the water demand of major water consuming sectors. The gap between supply and demand is about 11.5 million cubic meters per year, this gap compensated by overexploitation of groundwater [9].

The combination of the different technologies and different alternative energy resources and the development of this strategic sector especially for isolated areas certainly should come with favorable results to these communities.

Table 1a. Sustainable water yields in the kingdom of Saudi Arabia in 2010.

\begin{tabular}{|c|c|}
\hline Sustainable water yields & $\begin{array}{c}\text { Capacity } \\
\left.\text { (million } \mathrm{m}^{3} / \text { year }\right)\end{array}$ \\
\hline Groundwater & 3850 \\
\hline Surface water & $1300^{*}$ \\
\hline Total conventional Sources & 5150 \\
\hline Treated wastewater & 240 \\
\hline Desalinated water & 1050 \\
\hline Total non-conventional sources & 1290 \\
\hline Total water yields & 6440 \\
\hline
\end{tabular}

*Depends on annual rainfall pattern.

Part of the proposed solutions rely on the use of clean water produced after physical and chemical treatments in waste water treatment plants distributed throughout the kingdom being a viable source to cover the increasing water supply demand gap [10].
In this regard, Table 2 shows some useful data regarding the potable water supplies, waste water treatment plants capacity and the collected amounts in the main cities of the KSA reported in $1425 \mathrm{H} / 2004 \mathrm{G}$ [11].

Table 1b. Water demand of KSA in the year 2010

\begin{tabular}{|c|c|}
\hline Water demand per sector & Capacity (million $\mathrm{m}^{3} /$ year) \\
\hline Agriculture & 15,000 \\
\hline Industrial & 800 \\
\hline Domestic & 2063 \\
\hline Total water demand & 17,863 \\
\hline 2010 Water demand vs. supply gap & 11,423 \\
\hline
\end{tabular}

The data given in Table 2 shows the gap between the water supplies of 2.61 million $\mathrm{m}^{3}$ and the collected waste water amounts of 1.22 million $\mathrm{m}^{3}$, this means that more than $50 \%$ of the water supplied is disposed of due to the lack of treatment plants or that consumers are not connected to sewage and sewage network systems.

The physical and chemical treatment of these huge amounts of waste water and the desalting of the salty water are to be utilized to produce abundant quantities of public-utility water which will be very helpful to bridge the gap between water supply and demand in Saudi Arabia and elsewhere. Special attention should be taken for those isolated places in the dry and semidry regions everywhere. Extraction of water from its sources can be attained by separation of water from the main water masses containing dissolved salts and undissolved suspended solid particles.

This work treats with the exploitation of natural energy resources especially sun and wind motion energy for water separation from its sources by evaporating of water which can be used for domestic purposes after being treated as desired. The utilization of alternative energies that is abundant in KSA, the solar and winds motion energy, which can provide the necessary energy for water evaporation (latent heat of vaporization). We can rely on these sustainable forms of energy for producing electricity and heat needed to operate these units. At the first stage water is separated from other solid constituents by evaporation and then treated chemically, if necessary to remove chemically dissolved constituents and odors.

Table 2. Water supplies, waste water treatment plants capacity and the collected amounts of waste water in the main four cities of KSA.

\begin{tabular}{|c|c|c|c|c|c|c|}
\hline \multirow{2}{*}{ Description } & \multicolumn{4}{|c|}{ Name of City } & \multirow{2}{*}{$\begin{array}{l}\text { Total for the } \\
\text { four cities }\end{array}$} & \multirow{2}{*}{$\begin{array}{l}\text { Total for the } \\
\text { KSA }\end{array}$} \\
\hline & Riyadh & Jeddah & Madinah & Dammam/Khobar & & \\
\hline population & $\begin{array}{l}4137280 \\
(18 \%)\end{array}$ & $\begin{array}{c}2883169 \\
(13 \%)\end{array}$ & $\begin{array}{c}994175 \\
(4 \%)\end{array}$ & $\begin{array}{c}1200172 \\
(5 \%)\end{array}$ & $\begin{array}{c}9214796 \\
(41 \%)\end{array}$ & 22673538 \\
\hline Number of house holds & $\begin{array}{c}728221 \\
(18 \%)\end{array}$ & $\begin{array}{c}635001 \\
(16 \%)\end{array}$ & $\begin{array}{c}177404 \\
(4 \%)\end{array}$ & $\begin{array}{c}218642 \\
(5 \%)\end{array}$ & $\begin{array}{c}1759268 \\
(44 \%)\end{array}$ & 3990559 \\
\hline Potable water supply, $\mathrm{m}^{3} /$ day & $\begin{array}{l}1266000 \\
(23.5 \%)\end{array}$ & $\begin{array}{l}634000 \\
(11.8 \%)\end{array}$ & $\begin{array}{l}28000 \\
(5.2 \%)\end{array}$ & $\begin{array}{c}429000 \\
(8 \%)\end{array}$ & $\begin{array}{l}2609000 \\
(48.5 \%)\end{array}$ & 5391000 \\
\hline $\begin{array}{l}\text { Waste water treatment capacity, } \\
\qquad n^{3} / \text { day }\end{array}$ & $\begin{array}{l}612000 \\
(24 \%)\end{array}$ & $\begin{array}{l}274000 \\
(11 \%)\end{array}$ & $\begin{array}{l}240000 \\
(9.5 \%)\end{array}$ & $\begin{array}{l}342000 \\
(13.5 \%)\end{array}$ & $\begin{array}{c}1468000 \\
(57 \%)\end{array}$ & 2546626 \\
\hline Waste water collection, $\mathrm{m}^{3} /$ day & $\begin{array}{l}464000 \\
(29 \%)\end{array}$ & $\begin{array}{l}274000 \\
(17 \%)\end{array}$ & $\begin{array}{l}150000 \\
(9 \%)\end{array}$ & $\begin{array}{l}331000 \\
(21 \%)\end{array}$ & $\begin{array}{c}1219000 \\
(76 \%)\end{array}$ & 1602924 \\
\hline
\end{tabular}




\subsection{Evaporation}

The vaporization process of liquid water is achieved in two ways, the first which is called the evaporation in which vaporization of liquid occurs only on the surface of the liquid. The other type of vaporization is called boiling which occurs in the entire mass of the liquid and the liquid reaches the saturation temperature which depends on the pressures.

This phenomenon depends on the temperature, pressure, compositions of both water solution -vapor phase mixtures, on the Motion of air above the water surface itself and finally on the surface tension of the liquid phase.

Surface tension and evaporation are not as linked with each other for all systems. They are two distinct characteristics of liquids which generally follow direct relationship but not always. There are several other factors which one should not ignore.

One must remember that surface tension is the inherent force of liquid described by its tendency to minimize its surface area. Hence, a liquid with high molecular attraction takes account for a higher surface tension. It depends on temperature but it does not have similar dependency for all systems.

\subsubsection{Evaporation at Boiling with surfactants}

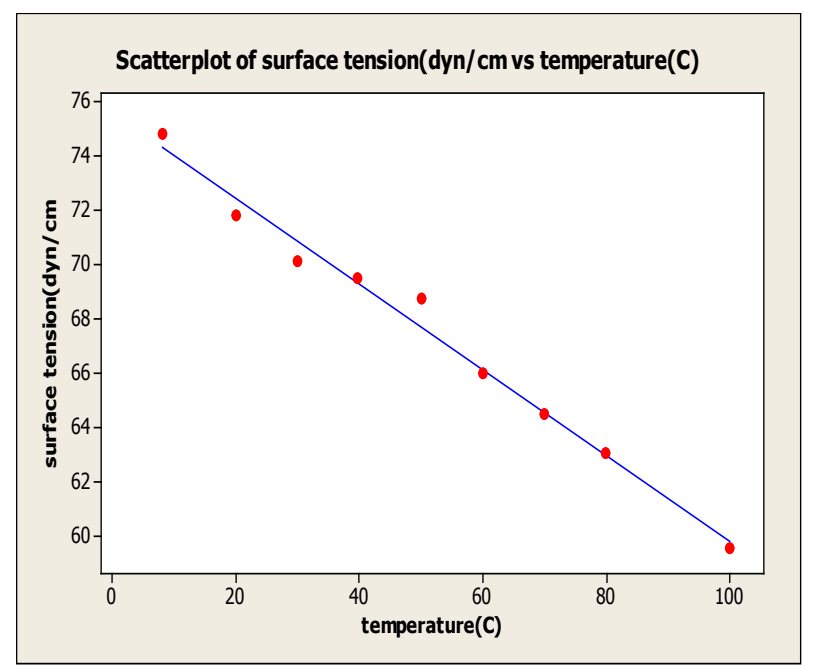

Figure 1. Graphical presentation of water surface tension vs. temperature

Surfactants and Boiling Nucleate boiling is a very efficient mode of heat transfer [12]. Boiling has many applications in energy conversion systems, heat exchange systems, air conditioning [12]. Boiling is also used in industry for steam production in turbines [13]. Surfactants can greatly enhance boiling performance. This can be accomplished at such low concentrations that no significant changes in physical properties other than surface tension are made [12]. The main factors assessed to be contributing to enhanced heat transfer are heat flux, surfactant concentration, surface tension, and molecular weight [13]. Surfactant type is also important as the ionic nature and molecular weight affect the boiling process itself [14]. For example, the accessible area and the hydrophobic interaction of alkyl chains can have significant effects on evaporation decay in boiling mechanisms [15]. Some surfactants enhance boiling heat transfer while others do not. For water, the relation between surface tension and temperature in the range between $8^{\circ} \mathrm{C}$ and $100^{\circ} \mathrm{C}$ is depicted in Fig. 1, which shows that for lower surface tension, we must move towards higher temperatures.

Operation at higher temperatures is to decrease the surface tension and to increase the chemical potential of water molecules promoting evaporation and hence increasing the rate of mass transfer from liquid to vapor.

Thus increasing the temperature, the rate of evaporation will increase. Another factor that affects the rate of evaporation is the partial pressure of water in the vapor phase (air and water vapor) which is related with the humidity of air in the neighborhood of the liquid phase. Our scope on this occasion is to increase the temperature in order to increase the rate of mass transfer from liquid to vapor phase. In order to keep the vapor phase always far away from equilibrium, we suggest collecting or trapping the water vapor by condensation and continuously collecting the droplets of condensed water droplets and sending them far away from liquid - vapor system.

Evaporation of water is a physical Phenomenon, where water changes phase from liquid to vapor leaving the metallic salts or non-vaporizing constituents dissolved or suspended in the residual water. This phenomenon needs energy to enable molecules to move from the liquid phase to the vapor phase. This energy is called the latent heat of vaporization $\left(\Delta \mathrm{H}_{\mathrm{v}}\right)$. Some values of $\left(\Delta \mathrm{H}_{\mathrm{v}}\right)$ are given in Table 3 .

Table 3. Latent heat of evaporation of water at different temperatures [16]

\begin{tabular}{|c|c|}
\hline $\mathbf{T}^{\circ} \mathbf{C}$ & latent heat of vaporization $\mathbf{, k J} / \mathbf{k g}$ \\
\hline 20 & 2454.3 \\
\hline 25 & 2442.5 \\
\hline 45 & 2394.9 \\
\hline 55 & 2370.8 \\
\hline 60 & 2358.6 \\
\hline 70 & 2343.0 \\
\hline 80 & 2308.8 \\
\hline 90 & 2283.2 \\
\hline 100 & 2256.9 \\
\hline
\end{tabular}

The decrease in the values of $\left(\Delta \mathrm{H}_{\mathrm{v}}\right)$ with increasing temperatures is attributed to the increasing in Gibbs free energy of the water molecules and the decrease in the surface tension of water at the interfacial liquid water /air surface area. 


\subsection{Water Cycle}

Evaporation is an essential part of the water cycle. Energy drives evaporation of water from oceans, lakes, moisture in the soil, and other sources of water. Evaporation and transpiration (which involves evaporation within plant stomata) are collectively termed vapor-transpiration. Evaporation is caused when water is exposed to air and the liquid molecules turn into water vapor, which rises up and forms clouds.

For evaporation to take place, molecules must be located near the surface, be moving in the proper direction, and have sufficient kinetic energy to overcome liquid-phase intermolecular forces. Only a small portion of the molecules meet these criteria.

Thus water cycle is the continuous motion of water molecules around the Earth. There are four main steps involved in this cycle i.e. evaporation, condensation, rainfall and rivers flow. When energy is gained by water, water evaporates and turns into water vapor and goes up into the atmosphere. This water vapor gets together with other water vapor and turns into a cloud. When clouds get dense, they drop the water back to earth in some form of precipitation like rain, snow etc. When the water falls back down to the Earth, they find their way on the ground surface into streams and rivers. Again this water will evaporate and the whole cycle will start again.

\subsection{Mathematical Models for Evaporation from Water Surfaces}

Water evaporation from open surfaces - like swimming pools or open tanks and reservoirs - depends on different parameters as mentioned above mainly on temperature of both water and air and on the humidity of the surrounding circulating air .

The amount of evaporated water can be expressed with the empirical equation as [17]:

$$
\mathrm{m}=\text { Se. } \mathrm{A}\left(\mathrm{H}_{\mathrm{s}}-\mathrm{H}\right)
$$

Where, $\mathrm{m}=$ amount of evaporated water per hour $(\mathrm{kg} / \mathrm{h})$, $\mathrm{Se}=$ specific evaporation rate, $\left(\mathrm{kg} / \mathrm{m}^{2} \mathrm{~h}\right)=(25+19 \mathrm{v})$

$\mathrm{v}=$ velocity of air above the water surface $(\mathrm{m} / \mathrm{s}), \mathrm{A}=$ water surface area $\left(\mathrm{m}^{2}\right)$

$\mathrm{H}_{\mathrm{s}}=$ humidity ratio in saturated air at the same temperature as the water content $(\mathrm{kg} / \mathrm{kg}),\left(\mathrm{kg} \mathrm{H}_{2} \mathrm{O} / \mathrm{kg}\right.$ dry Air)

$\mathrm{H}=$ humidity ratio in the air $(\mathrm{kg} / \mathrm{kg}),\left(\mathrm{kg} \mathrm{H}_{2} \mathrm{O} / \mathrm{kg}\right.$ dry Air) [18].

\subsection{Required Heat Supply}

Most of the heat required for the evaporation is taken from the circulating hot medium which is used to transfer energy to the water. To maintain the same water temperature, heat must be supplied.

The heat supplied can be calculated as:

$$
\dot{Q}=\dot{m} \cdot \lambda
$$

Where, $\dot{Q}=$ heat required $(\mathrm{kJ} / \mathrm{s})$

For $\lambda=2442.5(\mathrm{kj} / \mathrm{kg})$, (latent heat of of water evaporation $\mathrm{kJ} / \mathrm{kg}$ at $25^{\circ} \mathrm{C}$ ).

An open surface with water temperature $25^{\circ} \mathrm{C}$ the humidity ratio is approximately $0.0203 \mathrm{~kg} / \mathrm{kg}$. With a dry air temperature $25^{\circ} \mathrm{C}$ and $50 \%$ relative humidity the humidity ratio in air is $0.0097 \mathrm{~kg} / \mathrm{kg}$ [18].

For a swimming pool with $25 \mathrm{~m}$ length and $20 \mathrm{~m}$ width and of $3.6 \mathrm{~km} / \mathrm{h}$, i.e. $(1.0 \mathrm{~m} / \mathrm{s})$ velocity of air above the surface, the evaporation can be calculated as:

$$
\begin{aligned}
\mathrm{m} & =\left\{(25+19 * 1.0) \mathrm{kg} / \mathrm{m}^{2} . \mathrm{s}\right\} *(25 * 20) \mathrm{m}^{2} *(0.0203- \\
& (0.0097)) \mathrm{kg} / \mathrm{kg} / 3600 \\
& =0.0 .0647 \mathrm{~kg} / \mathrm{s} .
\end{aligned}
$$

The heat supply required to maintain the temperature can be calculated as:

$$
\mathrm{q}=(2442.5 \mathrm{~kJ} / \mathrm{kg})(0.0 .0647 \mathrm{~kg} / \mathrm{s})=158.03 \mathrm{~kW} .
$$

The required heat can be provided by directing concentrated light beams by using lenses that act as light beams concentrators on solar plates, also heat can be supplied through the advantage of the electric current produced through the windmills, the photoelectric phenomenon applying photovoltaic cells and heat gained using solar panels directly from the sun.

Energy emitted by the sun only that reaches the earth levels around 2200 thermal $\mathrm{kWh} / \mathrm{m}^{2}$ [19], the solar energy emitted by the sun had attracted many researchers to investigate this phenomenon [19-24]. The values reported by them regarding the solar energy emitted by the sun and reach the earth, were shocking and despite the differences in the values reported by them, the amounts of solar energy exceeded the needs of the inhabitants of the earth if exploited properly. David Wogan, Shreekar Pradhan and Shahad Albardi [24], reported an average value for the level of solar irradiance approaching $720 \mathrm{~W} / \mathrm{m}^{2}$. Thus for a pool of $500 \mathrm{~m}^{2}$ the amount of energy which can be utilized reaches $360000 \mathrm{~J} / \mathrm{s}$ i.e. $360 \mathrm{~kW}$ which is sufficiently higher than the needed energy for the vaporization of the 0.0647 $\mathrm{kg} / \mathrm{s}$ which is equal $158.03 \mathrm{~kW}$ at $25^{\circ} \mathrm{C}$. The mentioned value of $360 \mathrm{~kW}$ supplied from the sun must be utilized side by side with energy produced from the wind mills working days and nights. Studies on the wind energy done by N.M. Al-Abbadi[24] of five sites in Saudi Arabia based on data collected between 1995 and 2002 concluded the viability of using wind energy to power off and on-grid locations and the studies showed that the two cities of Dhulum and Arar, with average wind speeds of 5.7 and 5.4 $\mathrm{m} / \mathrm{s}$ respectively, are good candidates for off-grid wind turbines. The same study also concluded the viability of using grid connected wind turbines to partially power the two coastal cities of Yanbo and Dhahran with below average annual wind speed. Al abadi [25] supported that as much as 1080, 990, 730, 883 MWh could be produced using Nordex N43 wind turbine for Dhulum, Arar, Yanbu 
and Dhahran cities respectively.

The efficiency of sunlight can be increased through variation of many parameters as the color of the light absorbing surface assigned for sun light collection, the angle of inclination and the surface area of these light collecting surfaces. Evaporating pools can be provided with heating coils circulating hot water.

For this purpose we proposed a closed loop model to utilize the natural abundant available energy resources to provide the necessary energy for operating the whole unit.

The evaporated water may contain chemicals with unpleasant odors and must be treated for removing any unpleasant contaminant by physical and or chemical treatments.

\section{Proposed Process Model Description}

A schematic representation of the process flow sheet of the proposed model is shown in Figure 2.

Salty or waste water is fed to a cone-shaped reservoir which is equipped with heating coils applying hot water as a heating medium or electrical resistances fed with electrical current from photovoltaic cells or windmills.
In this model we present solar energy as a representative source of natural energy and windmills must be included in these units.

The evaporation takes place in the cone-shaped reservoir, condensed vapors in the form of droplets are captured on the internal side of the transparent tent-like cover of the cone shaped reservoir.

A reservoir placed on a specified height which depends on our requirements of the hydrostatic pressure for collected water utilization. A vibrating device is applied in order to vibrate and shake the cover as illustrated in Fig.2.

Water collected is stored in a tank assigned for this purpose.

Equilibrium is always broken through a continuous collection of all accumulating droplets by means of a cylindrical ring surrounding the cone-shaped reservoir.

This model can be established and operated by habitants living in cities and also in isolated communities where pools of areas with surface areas $25 \mathrm{~m}$ length and $20 \mathrm{~m}$ width and suitable depth and can produce water with a rate ranging from $132.5 \mathrm{~kg} / \mathrm{h}$ to $232.92 \mathrm{~kg} / \mathrm{h}$ which can cover partial the gap between demand and supply for these communities.

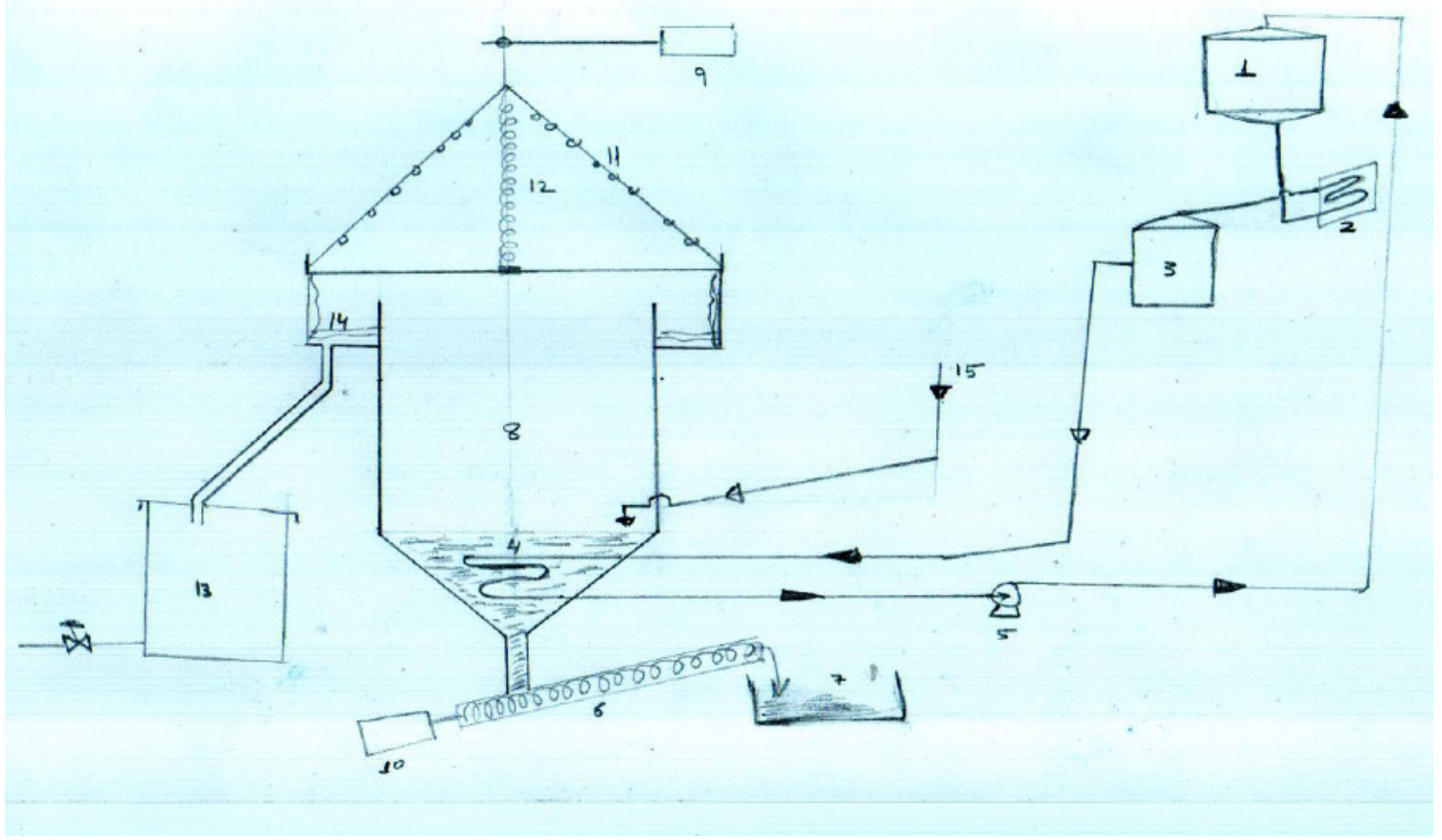

1- reservoir of recycled heating medium, 2-sun light collector, 3-reservoir for hot water, 4-heating coil, 5-heating water pump, 6-solid contaminations removing conveyor,7-solid wastes , 8-evaporation space(cone-shaped reservoir), 9-vibrating device, 10-conveyor's motor,11- transparent cone-like tent, 12-spring,13-treated water collection reservoir,14-condensed water .

Figure 2. Process flow sheet of the closed cell for water recovery from mixtures containing contaminated water 


\subsection{Necessary Supporting Operations}

In these units, some processes are necessary to improve the efficiency. Coagulation, sedimentation, granular media filtration, adsorption, ion-exchange, membrane filtration, slow sand filtration, and disinfection, and sometimes softening.

\subsection{Utilities}

Solar energy collecting plates are applied with the necessary tanks for the storage of both hot and cold water. Also photovoltaic cells and wind mills, electrical resistances are used to supply the necessary electrical current needed for light, pumping, vibrating and conveying devices.

\section{Conclusions}

Desalination and waste water treatment can compensate for major portion of the dry and semidry regions of Saudi needs and similar countries for water. Exploitation of alternative energy resources to operate the treatment plants and the combination of the different available technologies and different alternative energy resources and the development of this strategic sector especially for isolated areas, certainly should come with favorable results to these communities.

Simplicity of the proposed closed cell treatment model which can be operated partially by well-trained simple people operators.

Based on a simple calculation, Areas with $500 \mathrm{~m}^{2}$ and at moderate conditions, solar thermal energy only can produce between $3180 \mathrm{~kg}$ and $5590 \mathrm{~kg}$ of water/day covering the needs of approximately 50 habitants $(100 \mathrm{~kg}$ water/day. habitant).

The residents of the isolated areas will find themselves in a great blessing represented by the availability of mechanisms capable of providing a great deal of their needs of energy capable of securing their water needs and improve their lifes, wastes which were spoiling their environment and techniques dependent on the alternative energies where there is no need for the General Company for electricity or fuel tanks to meet their needs. Energy without contamination of soil and air and without the hassle of sound generators that operate with traditional fuels.

Produced treated water can be used for drinking, irrigation, cleaning, car stations, and for industrial purposes especially for the isolated communities which are in need for every amount of water.

Someday Saudi Arabia could become the Saudi Arabia of desalination, of waste water treated and of solar energy and generally for sustainable energy resources. It's possible that someday the world's largest oil producer could become the world's largest developer of sustainable energy resources from the Sun and windmills and other resources.

\section{REFERENCES}

[1] Khodran H. Al-Zahrani, Water Demand Management in the Kingdom of Saudi Arabia, Conference of international Journal of Art \& Science, 2(3):68-76, 2010.

[2] Pascale Compaina, Solar Energy for Water desalination, 1st International Symposium on Innovation and Technology in the Phosphate Industry [SYMPHOS 2011], Procedia Engineering 46 ( 2012 ) 220 - 227.

[3] Omar K. M. Ouda, Review of Saudi Arabia Municipal Water Tariff, World Environment 3(2): 66-70, 2013 ,

[4] Walid A. Abderrahman, "Groundwater Resources Management in Saudi Arabia", Special Presentation and Water Conservation Workshop, Al Khobar, Saudi Arabia, December, 2006

[5] World Bank, 2010. Making the most of scarcity: Accountability for better water management results in the Middle East and North Africa, Report, 2010.

[6] Al-Hussayen, H.E. Abdullah, Minister of Water \& Electricity, Water Situation in Saudi Arabia and MOWE's Initiatives Speech, Saudi Arabia Water Environment Association Workshop, 2007.

[7] Ministry of Economy and Planning, "the Eight Development Plan 2005-2008" Ministry of Economy and Planning Documents, Riyadh, KSA, 2005.

[8] MWE Supporting Documents for King Hassan II Great Water Prize, http://www.worldwatercouncil.org/fileadmin/wwc/Prizes/ Hassan_II/Candidates_2011/16.Ministry_SA.pdf(2012).

[9] Al-Zahrani, K.H., Elhag, E.A., Agricultural Development during the era of King Fahd, Book published by King Saud University, Riyadh, KSA, 2003.

[10] Odah, O.K.M., Impacts of agricultural policy on irrigation water demand: case study Saudi Arabia. International journal of water resources development, 30, 282-292, 2014

[11] Ministry of Water and Electricity Food and Agriculture Organization of the United Nation (FAO), Saudi Arabia. Irrigation in the Middle East regions in figures. Aquatat Survey -2008, FAO Land and Water, Division Report 34, PP 325-337.

[12] Cheng, L., Mewes, D., \& Luke, A. (2007). Boiling phenomena with surfactants and polymeric additives: A state-of-the-art review. International Journal of Heat and Mass Transfer, 50(13), 2744-2771.

[13] Dikici, B., Al-Sukaini, B.Q.A. (2016, June). Comparisons of Aqueous Surfactant solutions for Nucleate Pool Boiling. ASME 2016 Power and Energy Conference and Exhibition, Charlotte, North Carolina

[14] Wasekar, V. M., \& Manglik, R. M. (2000). Pool boiling 
heat transfer in aqueous solutions of an anionic surfactant. Journal of Heat Transfer, 122(4), 708-715.

[15] Zhang, J. T., \& Wang, B. X. (2003). Study on the interfacial evaporation of aqueous solution of SDS surfactant self-assembly monolayer. International Journal of Heat and Mass Transfer, 46(26), 5059-5064.

[16] J.M. Smith, H.C. Van Ness, M. M. Abbott, Introduction to chemical engineering thermodynamics, 7th edition, McGraw Hill, 2005.

[17] Engineering Tool Box, (2004). Evaporation from a Water Surface. [Online] Available at: https://www.engineeringtoolbox.com/evaporation-water-su rface-d 690.html

[18] Gordon J. Van Wylen, Richard E. Sonntag, Claus Borgnakke, Fundamentals of classical thermodynamics, $4^{\text {th }}$ edition, John Wiley \& Sons Inc. 1994

[19] Saleh H. Alawaji ,Evaluation of solar energy research and its applications in Saudi Arabia - 20 years of experience, Renewable and Sustainable Energy Reviews 5, 59-77, 2001.

[20] Claus Frohlich, "Construction of a Composite Total Solar
Irradiance (TSI) Time Series from 1978 to present", Physikalisch-Meteorologisches Observatorium Davos, 2006. Available: http://www.pmodwrc.ch/pmod.php?topic $=$ tsi $/$ composite $/$ SolarConstant

[21] Coddington, O.; Lean, J. L.; Pilewskie, P.; Snow, M.; Lindholm, D. (22 August 2016). "A Solar Irradiance Climate Data Record". Bulletin of the American Meteorological Society. 97 (7): 61265-1282. doi:10.1175/bams-d-14-00265.1. Retrieved 21 April 2018.

[22] Jump up^ "Introduction to Solar Radiation". Newport Corporation. Archived from the original on October 29, 2013.

[23] Dorathy A. Stewart Helmut P. Dudel Larry J. Levitt ,Technical Report RD-WS-93-6, Solar Radiationm in Saudi A rabia, Weapons Sciences Directorate Research, Development, and Engineering Center, June 1993.

[24] David Wogan, Shreekar Pradhan and Shahad Albardi, GCC Energy System Overview - October 2017 /KS-2017--MP0 4, 2017.

[25] N.M. Al-Abbadi, Wind energy resource assessment for five locations in Saudi Arabia, Renewable Energy, 30, pp. 1489-1499, 2005. 